\title{
THE DEVELOPMENT OF THE JUDICIAL SYSTEM IN RHODE ISLAND.
}

The first settlers in Portsmouth, Rhode Island, in 1637 , started out with a more definite judicial system than the other settlers in this state. They incorporated themselves into a "Body Politick" and then, following the example of the Old Testament, they elected a judge to exercise authority among themselves, his functions being, therefore, executive as well as judicial.*

Before the end of the first year of the existence of this infant community, the elders were associated with the judge, to help in the administration of justice and the drawing up of rules and laws "according to God." I Col. Recs., R. I., p. 63. They were directed to report quarterly to the town meeting for revision and approval, the ultimate source of power thus remaining in the town's freemen.

The next year a part of the settlers moved to the south end of the island and founded Newport. Those who remained at Portsmouth re-incorporated themselves again into a civil body politic under King Charles and "unto his laws according to the matters of justice." do., p. 70. They increased the number of elders to eight, with a more distinct delegation of judicial power

* The 7 th day of the first month, $x 638$.

We whose names are underwritten do here solemnly in the presence of Jehovah incorporate ourselves into a Bodie Politick and as he shall help, will submit our persons, lives and estates unto our Lord Jesus Christ, the King of Kings and Lord of Lords and to all those perfect and most absolute laws of his given us in his holy word of truth, to be guided and judged thereby.

$$
\begin{aligned}
& \text { Exod. 24: 3, 4. } \\
& \text { II Chron. II: } 3 \text {. } \\
& \text { II Kings Ir: } 17 .
\end{aligned}
$$

$$
\begin{aligned}
& \text { (Signed by) WILLIAM CodDINGToN } \\
& \text { and eighteen others. }
\end{aligned}
$$

The 7 th day of the first month, 1638 .

We that are Freemen Incorporate of this Bodie Politicke, do elect and constitute William Coddington, Esquire, a Judge amongst us, and so covenant to yield all due honour unto him according to the laws of God, and so far as in us lyes to maintain the honor and privileges of his place which shall hereafter be ratifyed according unto God, the Lord helping us so to do.

(I Col. Recs., R. I. 52.)

$$
\text { William Aspinwall, Sec'ry. }
$$


and a provision for trial by jury in cases of importance, but only one was "to be ruler or judge amongst us." do., p. 7o.

The settlers at Newport also confided judicial power to a judge with elders, the judge to have double vote however. do., p. 87 .

The next year, $x 640$, brought about the union of the two towns into a self-constituted state, a most remarkable occurrence, the full import of which has never been sufficiently recognized by historians. It was ordered that the Chief Magistrate of the Island should be called Governor, and the next Deputy Governor, and the rest of the magistrates, Assistants, and they were all invested also with the offices of Justices of the Peace. do., p. ror. Provision was made for courts, consisting of magistrates and jurors, to meet quarterly at Newport and Portsmouth alternately. do., p. I03. This system continued with slight changes until 1647 , when Providence and Warwick united with Newport and Portsmouth under the first charter.

If I have passed by until now the judicial systems of Providence and Warwick it is because there is little to be said on the subject until after the adoption of the first charter. It would seem that the Providence settlers transacted their judicial business, as well as all other public business, in town meeting, but the loss of the early records leaves the success of this system unknown to us. A provision for compulsory arbitration adopted in 1640 (do., p. 27) indicates that it had not worked satisfactorily-a result naturally to be anticipated from the known litigious character of these settlers.

The Warwick settlers maintained that they had no right to create a government for themselves without the sanction of the English government, so they remained without government until they joined the union of the towns under the first charter in 1647 , and therefore until then they had no judicial system.

Therefore, when the four separate towns or colonies united under the first charter, Providence had an unsatisfactory judicial system, the details of which are unknown to us, Warwick had no judicial system, and Portsmouth and Newport had a welloutlined system with judges and juries.

We come next to the judicial system after the adoption of the first charter and the remarkable code of laws then adopted. Each of the four towns had its president and four assistants. do., p. I9I. There was a general court of trials consisting of the president and the assistants from the towns, and this was the predecessor of our present Supreme Court. do., pp. xgr, 
192. This court was ambulatory, and in whichever of the four towns it met, the head officers of the town sat with it, but without any vote. This proved so unsatisfactory that in $165^{\circ}$ they were given "equal authority to vote and act with the general officers." Durfee, Gleanings from the Judicial History of Rhode Island, p. 9 .

There were also town courts for the trial of minor criminal and civil cases. In 1658 it was enacted that all causes, except cases of high crime, should be tried in the town courts, with a right of appeal to the general court. I Col. Recs. 237. This system remained in force until the reception of the royal charter in $166_{3}$, except during the interruption caused by Codding. ton's usurpation.

Under this charter the governor, deputy governor and assistants exercised certain judicial as well as executive functions. The charter did not create courts however; it authorized the General Assembly to create them. At its first session the Assembly directed a general court of trials at Newport every year in May and October (2 Col. Recs. 26)-afterwards altered to March and September (2 Col. Recs. 3I)-so as not to interfere with the sessions of the General Assembly, the court to consist of the governor, deputy governor, with at least six-then changed to three-assistants. Special courts were provided for urgent cases, and a local court for Providence and Warwick for petty cases.

The superior court thus created finally sat only in Newport instead of visiting all the towns, and it contained no town officers, both of which changes tended to raise the character of the court. But as the judges received no pay, their attendance was irregular, and to remedy this the number of assistants on the court was reduced and they were paid three, and afterwards four, shillings for each day's attendance, but they were fined twice as much for being absent without cause, and worse yet, a fine of five pounds for each absentee, when no quorum appeared. 2 Col. Recs. 64 .

The next important change was made in 1729 when the colony was for the first time divided into counties; * Newport County, containing the islands; Providence County, containing the old town of Providence, later divided into North

${ }^{*} 4$ Col. Recs. 427 . It is noteworthy that the act does not incorporate these counties; Bristol County is the only county in the state that is explicitly stated to be a corporation. 5 Col. Recs. 208. 
Providence, Smithfield, Foster, Gloucester, Scituate, Johnston, Cranston, Burrillville, and seven other towns; and King's County, now Washington County, containing the old towns of North and South Kingstown and Westerly, and now divided into eight towns. Bristol County was afterwards created (in r746-7) out of territory recovered from Massachusetts, and Kent County out of territory set off from Providence County. A criminal and civil court was established for each county with justices of the peace for minor offenses. ${ }_{4}$ Col. Recs. ${ }_{428}$. The criminal court was made up of the justices of the county and the civil court was made up of "four judicious and skillful persons" chosen by the General Assembly from the county they were to represent (do., p. 432), commissioned by the governor to hold office during good behavior, at first, but in 1733 their tenure was made annual. do., p. 484. The higher court met exclusively at Newport, under the title of "The General Court of Trial and General Goal Delivery," with jurisdiction in civil and mainly in criminal cases, declared to be as ample as that of the Court of Common Pleas, King's Bench or Exchequer in his Majesty's Kingdom of England. Pub. Laws, 1730, p. 7. This lasted for nearly a century, in spite of the disadvantages resulting from its meeting only in Newport and from the political character of the court, consisting, as it did, of the governor or deputy governor and the assistants, who might or might not happen to be qualified for judicial work. It could not have sufficed had this judicial work been other than very simple and with but little development of equity powers.

In 7746 two changes were made, rendered necessary by the increase of business and population.*

The General Assembly thereafter chose annually five judges, a chief justice and four associate justices, and provision was made for two sessions a year in every county. Thus an important step was taken in separating the judicial from the executive function. We shall see later that the complete separation of the judicial from the legislative function did not take place until after the adoption of the constitution in $x 842$. It is interesting to follow the steps by which the three important divisions of the government-the legislative, the executive and the judicial-have become separated. At first they were all exercised by the General Assembly. Then came the first crude

* See also the Act of I746, p. 27, P. L. of R. I., from I745 to I752, entitled "An Act for the more regular Establishing a Superior Court of Judicature, Court of Assize and General Delivery throughout the Colony." 
separation of the judicial from the executive power, in 1746 . In I780 the General Assembly declared by preamble that it was incompatible with the constitution of the state for legislative and judicial powers to be united in the same person, and therefore it was enacted that after the next election, no member of either house of the General Assembly should fill the office of a justice of the Supreme Court. In I833 a similar act debarred judges of the court of common pleas from sitting in the General Assembly. Apparently no one saw the inconsistency of thus barring the judiciary from the legislature while continuing to allow the legislature to exercise judicial power and that degree of political development was not reached until the middle of the next century.

As all powers were originally exercised by the General Assembly, when it became necessary to distinguish between them, there were two ways in which this could be done-either by grant from the General Assembly or by assumption of the power by the executive or judiciary. Courts have always, in part at least, increased their jurisdiction, by the assumption of power, indeed so well is this known, it has led to a maxim of the law that the good chancellor is he who increases his jurisdiction. Our courts in Rhode Island have increased their powers in some respects by assuming jurisdiction, especially in equity, and particularly so since the adoption of the present constitution in 1842 . But it was more natural, during our earlier history, when our legislature was strong and our judiciary was weak and not composed of lawyers, that the source of increased jurisdiction of the judiciary should be the legislature, and that is where we find it. See P. L. 1767, p. 74 .

In 7749 the superior court was authorized to grant divorces, a power theretofore exercised by the General Assembly. As Judge Durfee says, in his "Gleanings from the Judicial History of Rhode Island": "Contrary to the usual belief, the causes for divorce remain still almost the same as they were fixed by the General Assembly in 1798." At Page 35. Judge Durfee gives further examples, as follows, of the exercise of judicial powers of the General Assembly before their delegation to the courts of law:

"Thus the assembly early began and long continued to grant divorces. In 1665 it granted a divorce for adultery of the wife on her confession and at the same time sentenced her to pay a fine and be whipped. In $x 667$ a husband and wife joined in petitioning for divorce. The assembly could find no cause for 
divorce, but authorized them to live apart. In $x 667$ John Belew petitioned to be divorced from his wife, and the assembly, finding from the first they had "lived very discontentedly, she complaining of his insufficiency," granted the petition. Sometimes the assembly granted alimony as well as divorce, or, in case of desertion by the husband, sequestered his estate for the support of the wife and children without a divorce. Just, but despotic! Of course after power to divorce was granted to the superior court, the jurisdiction languished, but it continued, nevertheless, to be invoked in exceptional cases, which either were not provided for by statute or were too flimsy or too whimsical for judicial treatment. There is an uncanny tradition, still vaguely surviving, that in such cases grave legislators were sometimes plied in the lobby with solicitations and arguments too peculiar for public discussion. After the constitution the more usual course for the assembly was, not to hear the petition, but to authorize the Supreme Court to hear by special act, if without such act the court was incompetent. Divorces, however, were granted as late as $r 85^{\circ}$. In January, $185 \mathrm{r}$, the assembly had several petitions pending before it and transferred them, together with all documents and depositions in support of them, to the Supreme Court, "where," the resolution of transfer tartly remarks, "the said petitions should have been filed," and at the same time authorized and required the court to try them.

The same body continued to exercise jurisdiction in cases of insolvency until 1832 , when a statute confined it to the Supreme Court (see P. Laws, Ed. of r844, p. 2 IO), reserving, however, a right of appeal to the General Assembly, and this continued until 1857, when the decision in the famous case of Taylor $v$. Place, 4 R. I. 324, put an end to it.

We have seen that our Rhode Island forefathers did not consider a knowledge of law essential to a judge.* Together with

* Nor did the judge charge the jury, probably because, if a layman, he did not know how to. The code of I647 directed the charging of the jury by the court, but in 1699 , in a report of the Earl of Bellomont to the English Government, it is stated that the courts in this colony "give no directions to the jury nor sum up the evidence to them." This remained the custom until about I833, as appears from the charge to the jury in the famous trial of Ephraim K. Avery, charged with the murder of Sarah M. Cornell:

"Until the statute, passed within a few years, making it the duty of the presiding judge to charge the jury upon the law, no court in this state had adopted the practice of instructing the jury upon the application of the law to the facts. The construction this court has placed upon the statute is, never to sum up the facts in the case, but merely to explain the law upon a supposed state of facts, and leave the jury to determine the facts, and apply the law. 
this ignorance of law there was a contempt for lawyers and a vague dread of equity, perhaps the result of traditions and vague remembrances brought from England by the first settlers who lived during the exercise of star chamber methods in England and the times when the conflict raged between the system of common law and the development of equity powers. This conflict culminated in the contest for supremacy, aggravated by personal motives and bitter personal feelings between Coke, the great Chief Justice of England, the representative of the common law system, and Lord Bacon, the great Chancellor, the representative of the equity system.

Equity powers were slowly developed in Rhode Island, and indeed there was at first but little opportunity for their development in the simple life of the early settlers here. It is not proposed now to treat of the exercise of equity powers by the General Assembly, but only of the conferring of such powers by the legislature upon the judiciary. The first grant was in I667 (see p. 6r P. L. I667), and was a grant to proceed according to the rules of equity where any penalty, conditional estate or equity of redemption was sued for, and to chancerize forfeitures. It was not until 1798 (Laws I798, p. 274) that the court was empowered, by an act of the General Assembly, to entertain $a$ bill in equity to redeem a mortgage, and not until 1822 (Laws I822, p. 2Ir), within almost the memory of men now living, that the court could entertain a bill to foreclose a mortage. These few examples are enough to show how far behind the mother country we were in our exercise of chancery or equity powers by our Supreme Court. This is still further shown when we find that it was not until I829 (Laws, Oct. Session, 1829 , p. 46), that the court acquired jurisdiction, by act of the General Assembly, over cases relating to trusts created by assignments for the benefit of creditors; not until 1836 over cases relating to trusts generally, to controversies between co-partners (Laws, Jan, 1836, p. 48 , and do., June, 1836 , p. 94), to proceedings against banks for forfeiture of charters and to bring about liquidation; not until 1837 (Laws 1844. p. 9I) over cases against railroad and turnpike corporations to restrain violations of their charters, and not until $184 \mathrm{I}$ was the Supreme Court vested by the General Assembly with full equity powers in case of fraud generally (Laws 1844, p. 89). It is true that to a limited extent the General Assembly exercised general equity powers until the Constitution of 1842 was adopted, but if we try to imagine the results of such exercise of these powers by 
the General Assembly now, when, with the general improvement in education, it is better fitted for their exercise than it was in "ye olden times," the dire results can easily be foreseen, and we have an explanation of the fact that persons having occasion to bring a bill in equity in the last century, prior to I842 constantly moved out of the state across the line into Massachusetts or Connecticut, to effect a change of citizenship to enable suit to be brought in the United States Court, where that eminent equity judge, Story, presided.

The dread of equity powers is shown to have continued even down to $r 842$ by the provision in the Constitution then adopted that chancery powers can be conferred only on the Supreme Court. The statutes, as revised after this constitution was adopted, for the first time invested the Supreme Court with full equity jurisdiction and the golden age of the development of this new jurisdiction was fortunate in having at its head our eminent Chief Justice Ames. Fortunate indeed are the older members of our bar who have lived and taken part in this important period of our development of the equity side of our court. But as regards the common law side of our Supreme Court a retrograde step was taken in 1847 when the Supreme Court was vested with original jurisdiction, concurrently with the court of common pleas, over all civil suits for not less than one hundred dollars-later, not less than three hundred dollars. For a Supreme Court should be what its name implies-a court above all others, a court of last resort, both in law and in equity, to pass upon the law only. If in addition to these functions, the court is to be also a court of first instance, where is the court of last resort to which an appeal can be taken?

The act that thus minified the dignity of the higher court also continued another peculiarity that lasted until 5878 -the right to two jury trials. The result was, generally, that the first trial was but a preparation for the second trial. Sometimes there were three jury trials-i. e., in the court of common pleas; second on appeal, in the Supreme Court; and third, if the two verdicts were contradictory, one more trial was given, to determine which was right. In order that the ever-increasing business of the court might be disposed of, in 1852 the previous practice, of having all the judges sit, without regard to the kind of judicial business to be attended to, was changed, and one justice was authorized to preside at jury trials and was constituted a quorum for certain specified purposes. Schedules May Session, I852, p. 115. This enabled the different justices 
to hold court at the same time in the same or in different counties, reserving for the full bench appeals in questions of law and also all equity cases. A still further extension of this sysiem has led in recent years to the division of the Supreme Court itself, concerning which more will be said later.

Another failure to keep the Supreme Court separate from all others was made in 1843 , when the courts of common pleas were re-organized, and were made to consist of a justice of the Supreme Court as the chief justice thereof, with two associates chosen annually by the General Assembly from the different counties.

In 1848 the two associates were dispensed with, and ever since then the judge of the court of common pleas has been one of the justices of the Supreme Court. Schedules, May, r848, p. 7 .

The right of the General Assembly to act as a court of appeals, to exercise prerogative powers over the proceedings of the courts of the colony or to give relief as a court of chancery, was denied by the home authorities and was occasionally repudiated by the General Assembly itself.

Thus in 1678 a petition was preferred to the General Assembly to reverse a judgment for the defendant in the case of Sanford $v$. Foster that had been tried twice in the general court of trials. The General Assembly refused to interfere, declaring by their vote, "This Assembly conceive that it doth not properly belong to them, or is any wise within their recognizance, to judge or reverse any sentence or judgment passed by the General Court of Tryalls according to law except capitall or criminall cases or mulcts or fines." 3 Col. Recs. 19.

In May, r68o, however, the General Assembly voted, "that in all actional cases brought to the Generall Court of Tryalls, if either plaintiff or defendant be aggrieved, after judgment entered in court, they may have liberty to make their appeale to the next Generall Assembly for reliefe, provided such appeale be made in the Recorder's office tenn days' time after judgment entered as aforesaid; as alsoe such person or persons so appealinge, shall first pay costs of court, and give in bond as in case of review, and thereupon execution shall be stopped till the determination of the Assembly be knowne." 3 Col. Recs. 87 .

It is to be borne in mind that the court of trials from which the right of appeal to the General Assembly was thus given, was composed of the governor and the assistants, one from each town, who then sat in the General Assembly as members of that body, and who were constituted a separate house of the 
General Assembly, by an act passed at the May session of the General Assembly, 1696. 3 Col. Recs. $3^{\text {r3 }}$. This would seem to be the effect of this act, for it does not expressly provide that the upper house shall sit by itself, only that "all the Deputies of each respective town shall sit as a House of Deputies for the future and have liberty to choose their Speaker among themselves and likewise the Clerk of the Deputies; and that the majority of the Deputies so assembled, shall be accounted a lawful House of Deputies." 3 Col. Recs. 3 I3.

The evolution of the Senate in Rhode Island forms a curious chapter in our history. It had been the custom to allow ex-assistants to sit in the General Assembly, in the absence of a full delegation from any town. In 1666 the towns of Portsmouth and Warwick petitioned the General Assembly that the deputies, or, as we now call them, the representatives, should sit apart from the magistrates as a house by themselves. This was enacted that year (2 Col. Recs. 144), but the act was soon repealed-in 1672 (2 Col. Recs. 472 )-and the two continued to sit together, until the Act of 1696 .

The charter of Charles II provided there should be ten assistants to be chosen by a general ticket. When the Town of Kingstown was divided into two towns in I722, the General $^{2}$ Assembly provided that each of them should have one assistant and hence arose the custom of choosing the assistants, one from each town. This has continued to the present time in the constitution of the State Senate, composed of one member from every town in the state. 2 Arnold, Hist. of R. I. 70. This body was for a long time called the Council. In $I 789(d o ., 555)$ it was called the Upper House. This tendency towards one assistant from each town was a reversion to the custom established under the charter of 1643 .

In $1688-9$ instructions were given by the Board of Trade in England to the Earl of Bellomont, Governor of New York, Connecticut and Massachusetts, to inquire into and to report upon complaints made against this colony for the independent manner in which its affairs were managed. In his letter to the Board of Trade, dated November 27, 1689, he wrote:

"§II. The Generall Assembly assume a judicial power of hearing trying and determining of civil causes, removing them out of the ordinary Courts of Justice and way of tryall, according to the course of the common law, alter and reverse verdicts and judgments. The Charter committing no judiciall power and authority unto them. . . " 3 Col. Recs. 386. 
One of the most peculiar features of the judicial system of Rhode Island has always been and now is, its probate system. In 1647 the head officer of the town had probate jurisdiction (I Col. Recs. 188), but the office of head officer was abolished and in 1674 the town councils became probate courts. 2 Col. Recs. 525. If one died intestate, the code of $x 6_{47}$ vested power in the town council sitting as a court of probate, to dispose of his property. Judge Staples called attention to one case in Providence where the council thus disposed of part of the real and personal estate to the widow, part for life and part in fee, and divided the residue among the children as tenants in tail general, with cross remainders.* This extraordinary power placed in the hands of men who were not lawyers, was made subject to appeal to the Senate or Governor and Council, in 1663 , as "Supreme Ordinary of Judge of Probate" and this continued until 1822 (P. L., r822, p. 212), when appeal could be taken to the supreme judical court and afterwards to the Supreme Court. This is the system still existing, except that in the cities and some towns, as population has increased, a probate court of one judge who is a lawyer, has been instituted. Despite the encomium of Judge Durfee (Gleanings from the Judicial History of Rhode Island 33), the system is far from ideal, and the commissioners who made the last revision, recognizing the faults of the system, proposed a different one, that was laid to rest, however, in the General Assembly. The fees allowed to the members of the town councils, when they sit as probate judges, may account in part at least, for the reluctance to change the system, and for the defeat of the draft of a reformed probate system proposed by the commissioners appointed in 1890 to revise the statutes, and submitted by them to the General Assembly. It is probable that the commission upon the revision of our judicial system will recommend important changes in its report this winter to the General Assembly.

In addition to the delegation of equity powers by the General Assembly to our courts, the General Assembly itself continued to exercise equity powers directly until the decision in Taylor v. Place, 4 R. I. 324, after the adoption of the present constitution. put an end to it. One reason why equity powers

\footnotetext{
* "The Proceedings of the First General Assembly of 'The Incorporation of Providence Plantations' and the Code of Laws adopted by that Assembly in 1647," by Wllliam R. Staples, 1847 .
} 
were slow in developing in this country, in addition to the reasons already given, is because the principles of equity jurisprudence and jurisdiction, as well as the system of equity pleadings, were also of slow and late development in England. Lord Nottingham, "the father of equity," became Chancellor in I673. It was not until 1756 , when Lord Hardwicke terminated his twenty years' service as Chancellor, that equity became molded into something like a rational system of jurisprudence. The sources from which a knowledge of its principles, the scope of its jurisdiction, as well as of the methods of procedure and of the rules of equity pleading and practice, were derived, were known only to the few persons in actual practice in equity courts, and to those having access to the manuscript notes that a few judges and solicitors were industrious and enterprising enough to make. No separate treaties on equity existed until after our separation from the mother country, and that is recognized as the time when law in the United States branched off from its source. From that time English statutes ceased to apply here and English precedents, although cited and treated with respect, ceased to be necessarily followed, or to be admitted to be absolute authority. Cathcart v. Robinson, 5 Pet. 280, by Marsha1l, C. J. Blackstone's Commentaries appeared from $\times 756$ to 1769 . In writing of equity he says it deserves a more complete explanation, "Yet as nothing is hitherto extant that can give a stranger a tolerable idea of the courts of equity subsisting in England, as distinguished from the courts of law, the compiler of these observations cannot but attempt to make it with diffidence; those who know them best are too much employed to find time to write, and those who have attended but little in those courts must be often at a loss for materials." B1. Comm., Bk. III, p. 429.

These facts are enough to account for the slow growth of equity, not only in Rhode Island, but in the American colonies generally, the absence of courts of chancery until in colonial history, and the informal and anomalous methods of administering equity that prevailed, but it is nevertheless evident that although little understood and irregularly administered, equity jurisprudence was a recognized part of the general system of the law of Rhode Island, as well as that of the other English colonies.

The General Assembly claimed that it was in itself a court of equity and that it continued to be such a court by an act passed in 1705 (3 Col Recs. 550) entited,"An Act for the General 
Assembly to be continued to be a Court of Chancery, untill such time as a Court of Chancery can be created."

The Act is as follows:

"Whereas, it hath been represented to this Assembly the great benefit that it might be, to have a Court of Chancery erected and settled in this her Majesty's Collony; but this Assembly having considered the rules and methods for the way and proceedings in such a Court, with the rules and constitutions thereof, being of great weight and concernment, and requires mature consideration for orderly settling thereof, which we conceive cannot at present at this Assembly be settled:

"Therefore be it enacted by the Honorable the Governor with the House of Magistrates and Representatives convened in Generall Assembly, and it is hereby enacted by the authority of the same, That the Generall Assembly at all times convened in Generall Assembly, shall be a Court of Chancery as formerly it hath been, until such time as a more proper Court of Chancery may be conveniently erected and settled."

We are fortunate in having the record easily accessible of a case, that of Brenton v. Remington, in which the General Assembly exercised jurisdiction as a Court of Chancery. As a concrete example illustrative of this exercise of jurisdiction, let us examine this case. Brenton brought an action in trespass and ejectment against Remington, to recover a tract of land that Remington had held for more than twenty years under a mortgage given by Brenton when owner of the land. Judgment was rendered against Brenton in the Court of Trials, whereupon he appealed to the General Assembly, which "being resolved into a General Committee," allowed Brenton to redeem on paying the debt and interest-that is to say, it treated Brenton's appeal as a petition in equity to redeem-in itself a sufficiently remarkable performance to a lawyer of our times.

The report of the proceedings is as follows

"Both houses being full, resolved into a grand committee, to hear appeals.

"Jahlee1 Brenton, Esq., appellant, Capt. Stephen Remington, appellee; the vote of the Assembly is as followeth, viz:

"Jahleel Brenton, of Newport, eldest son, and executor of the last will and testament of William Brenton, Esq., deceased, otherwise called Jahleel Brenton, of Newport, aforesaid, Esq., appealing to this Assembly, as a Court of Chancery, for relief against Capt. Stephen Remington, of Jamestown, appellee, for withholding from said appellant a certain tract or parcel of land in the Town of Jamestown, alias Cononicutt, in said colony. The said appellant also praying that the judgments of courts and verdict of juries against the appellant, in an action 
of trespass and ejectment, brought by the appellant against the appellee, at the Court of Trials, in March and September last past, for illegally withholding from (the said) appellant, the said tracts or parcels of land, aforesaid, of two hundred and fifty-six acres, more or less, may be reversed, and that the appellant may be put in possession of said tracts or parcels of land.

"This Assembly being resolved into a grand committee, as aforesaid, and settled a Court of Chancery or Equity, and hearing the several papers, evidences, and pleas on both sides, and maturely weighing and considering the same, with the circumstances and equity of the whole case; and whereas, the said appellant hath produced several laws which doth plainly hold forth, that upon extraordinary occasion, the mortgager shall have liberty to redeem a mortgage, notwithstanding the twenty years being passed; being the time limited in the law for the redemption of mortgages; and this case appearing to us to be extraordinary:

"Be it therefore enacted by this present Assembly and the authority thereof, that the said Jahleel Brenton, appellant, hath hereby liberty to redeem the mortgage of the above said lands and premises, he paying the principal money, with the interest, and lawful charges thereon, according to the purport of said mortgage; and the appellee to pay the charges in this Assembly.

"Upon which vote of the Assembly, Major Nathaniel Coddington, one of the attornies for the appellee, appeals to her Majesty in Council, in the Kingdom of Great Britain." 4 Col. Recs. 48.

The subsequent "Proceedings of the General Assembly held for the Colony of Rhode Island and Providence Plantations, at Newport the 27 th day of February, I7II-12 (4 Col. Recs. 136), were as follows:

"Whereas, this Assembly having taken into their serious consideration their jurisdiction and authority as an Assembly, for the trial and determination of appeals from the Court of Trials, especially respecting title of land; together with the judgment and determination of her Majesty and council upon the appeal of Remington against Brenton, wherein the proceedings of the Assembly were utterly condemned:

"Whereupon, notwithstanding a former act of this colony, which hath constituted and empowered the Assembly to be a Court of Chancery, we judge that they had no power or authority to make any such law, by reason we cannot find any precedent, that the legislators or Parliament of Great Britain, after they had passed an act or 1aw, took upon themselves the executive power or authority of constituting themselves the Court of Chancery, or any other Court of Judicature:-

"Yet, notwithstanding, considering the power and authority of the General Assembly of this colony, granted them by, and 
in our royal charter, do find that their power and authority is very large, and copious as legislative, to make laws and constitute courts of judicature for trial and decision of all matters and cases happening within this colony or government, as they shall judge proper, according to the constitution thereof, so as they be not repugnant, but as near as may be agreeable to the laws of England:

"Therefore, be it enacted by this present Assembly, and the authority thereof and it is hereby enacted, that the law of this colony, which constitutes, authorizes and empowers the Assembly to be a Court of Chancery, shall be, and is hereby repealed, made null and void, and of none effect; and that no appeal from the Court of Tryals for the future, be granted, allowed or brought before the Assembly of this Colony; and that the gentlemen appealing to this Assembly be dismissed, without any cost, save officers' fees.

"And also, that the Assembly of this colony, according to, and by virtue of their power and authority afore recited, shali erect, set up and establish a regular Court of Chancery, within this government according to the methods and precedents of Great Britain; any act or acts, law or laws of this government to the contrary thereof, in any wise notwithstanding.

"Always provided, the said appeals may be by way of peti. tion to this, or any other Assembly in this colony, have relief in any matter or thing that may be cognizable before them; or that may at any time hereafter, when a proper Court of Chancery be stated, have their appeals continued to said court of relief. if they shall think fit to prosecute the same."

In $144 \mathrm{I}$ it had become so evident that there should be a change made and that the General Assembly should cease to exercise chancery powers, at least to a certain extent, that an act was passed "for appointing and erecting a court of equity, to hear and determine all appeals in personal actions from the judgment of the superior court." 5 Col. Recs. 22.

A court of five judges was elected, to be chosen annually, to hear all such appeals, "to give a determination on said appeals, by affirming, reversing or altering the judgments of said superior court, agreeably to law and equity, in as full and extensive manner as the General Assembly hath been accustomed to do."

But for some reason that does not appear upon the record, it would seem that this system did not work satisfactorily, for in r744, this act was repealed, the preamble of the repealing act stating: "It is found by experience that the trial of causes by the said court of equity is inconvenient, and a great grievance to the inhabitants of this colony." 
The General Assembly also assumed unto itself another of the powers exercised by a court of equity--the power to punish for contempt. In 5757 (6 Col Recs. 5) we find that-

"Whereas, Samuel Thayer who was apprehended and brought before this Assembly, at their last session, for grossly abusing them, has not yet made satisfaction for the same,-

" $\mathrm{Be}$ it therefore resolved by this General Assembly, and by the authority thereof, it is resolved, that the said Samuel Thayer be immediately apprehended and committed to his Majesty's jail, in Providence, for his said abuse, and there remain confined, until further orders from this Assembly."

It would seem, however, that Samuel Thayer had not been imprisoned, for we find the order was repeated sixteen days

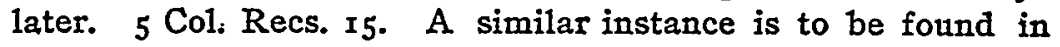
5 Col. Recs. 2o, occurring the same year.

It is an undoubted fact that appeal lay to the privy council in England and it is equally clear that the General Assembly of this colony had no power whatever over such appeals. Yet in 177 I the General Assembly attempted to limit this absolute right, by a resolution "that no person or persons whatsoever, shall hereafter be allowed or permitted to appeal to his Majesty in Council in Great Britain, from the judgment of the superior court of judicature in this colony, for any matter or thing whatsoever, unless the matter or thing in controversy be of the value of $\$ 300$ lawful money, to be valued by the court where the appeal shall be prayed; any law, custom or usage to the contrary hereof in any wise, notwithstanding." 7 Col. Recs. 33.

It is to be presumed that this was the act that was repealed in 7775.7 Col. Recs. 355. Whether it was repealed because of doubt as to the legality of the act or because it was intended to put a stop to all appeals to the privy council does not appear. This repealing act was passed in June, 1775 , only two months after the affair at Lexington and Concord and three years after the destruction of the Gaspee.

Another interesting exercise of power by the General Assembly is shown by the act passed in 1780 (9 Col. Recs. 156 ), establishing a court of admiralty in this state. When we joined the Union nine years later, of course all jurisdiction in admiralty became vested in the courts established in pursuance of the Constitution and this ended the exercise of power over admiralty matters by the General Assembly. It is one of the curiosities of legislation in Rhode Island that the Code of $I 647$ adopted the Laws of Oleron. "It is ordered that the Sea Lawes 
otherwise called the Lawes of Oleron shall be in force among us for the benefit of Seamen (vpon ye Island) and the Chief Officers in the Towne shall have power to summon the Court and determine the cause or causes presented." I Col. Recs. $15^{x}$. As this was never repealed, it follows that these laws remained in force until Rhode Island lost jurisdiction over all matters in admiralty by the adoption of the Constitution of the United States.

The Constitution of this state, adopted in 1842 , brought about great changes in the exercise of judicial powers by the General Assembly, although it was not until the decision by Judge Ames in the great case of Taylor $v$. Place in 1854 (4 R. I. 324) that the General Assembly was brought to a realizing sense of the fact that it could no longer exercise judicial powers either in law or equity.

Article III of the Constitution provides that "the powers of the government shall be distributed into three departmentsthe legislative, executive and judicial."

Article X, Section r, provides, "The judicial power of this state shall be vested in one Supreme Court, and in such inferior courts as the general assembly may from time to time, ordain. and establish."

Here was no express explicit statement that the General Assembly should no longer exercise any judicial power. Partly because of this omission, partly because the General Assembly always had exercised judicial powers, it continued still to exercise them after the adoption of the Constitution, sheltering itself under the vague Section ro of Article IV: "The General Assembly shall continue to exercise the powers they have heretofore exercised, unless prohibited in this Constitution."

The case of Taylor v. Place (4 R. I. 324), was brought to the Supreme Court in $185^{6}$ to test the constitutionality of an act of the General Assembly granting a new trial in a case brought by the Places in consequence of their having petitioned for such a new trial, the case having been decided against them. James Tillinghast was attorney for the Taylors, who were resisting the attempt to grant a new trial and who therefore maintained that the General Assembly could not grant a new trial, as that would be the exercise of judicial power which is forbidden by the Constitution. With Mr. Tillinghast, who is still with us, in the active practice of his profession, was associated Charles S. Bradley, afterwards Chief Justice. So ingrained was the notion in Rhode Island at the time that notwithstanding the 
Constitution, the General Assembly could still continue to exercise judicial powers, even many members of the bar were convinced that the court would sustain them in the exercise thereof. But in a masterly decision that should be studied by every educated man in Rhode Island, who would know the history of the state, Judge Ames held that ours is a government of three coördinate departments-the legislative, the executive and the judicial-and that the grant of judicial powers to the judiciary is the exclusion of the right to its exercise by the legislature.

In I822 the Supreme Judicial Court consisted of one chief justice and four associate justices. The law provided that "they or any three of them shall be a court," etc. Laws, x822, p. 10\%. It is obvious that under this law there could be but one Supreme Court, and this was as it should be. But Pub. Laws, I844, p. 92, state, "Sec. I3. Said court shall consist of one chief justice and three associate justices, and they or any two of them shall be a court," etc.

It is obvious that if two judges should constitute a court under this section, there could be two supreme courts at the same time, each composed of two judges. This is interesting and also important, for we find here the germ of the difficulty that finally culminated in the amendment to the Constitution adopted I903. The possibility of these two supreme courts must have presented itself to the minds of the drafters of this law, but they relied, in all probability, upon Article X, Section $I$, of the Constitution, then only two years old, that provides "The judicial power of this state shall be vested in one supreme court," etc.

Of course it was not probable that two judges should call themselves the court and that the other two should array themselves against them and say, "We are the court." In that case either set of two judges had as valid a claim to be considered the court, as the other, but fortunately the difficulty never arose. It is possible, however, whenever a quorum is constituted of less than a ma jority of the court with authority to hold separate courts, as a "Division" by one or more of the justices.

Under the revision of the laws in 1857 the same possibilities of difficulty were continued. Section I of $\mathrm{Ch}$. $\mathrm{r} 64$ provided that the Supreme Court shall consist of a chief justice and three associate justices, while Section 28 provided that "any two of said justices shall be a quorum of said court for all purposes and business whatsoever." Under this language it, might 
perhaps be claimed that in case of conflict, the first two judges that met together, as they constituted a quorum, constituted also the one supreme court contemplated by the Constitution. In this case the victory would rest with the two judges that met together first as the court, in an unseemly scramble or race for the court house. The contingency never arose, but it was possible and such a possibility was never contemplated, when the Constitution was drawn. Section 29 provided that. "The said court may be held by different Justices thereof, at the same time and in different places, in the same or some other county, for all purposes, civil or criminal, proper to the court as constituted."

The same state of things was continued under the revision of I872. Section I of $\mathrm{Ch}$. $\mathrm{x} 8 \mathrm{I}$ provided that, "The supreme court shall consist of a chief justice and three associate justices. to be elected, commissioned and to hold their offices as prescribed in the constitution, and any two justices thereof shall constitute a quorum."

In 1875 the increase of business before our courts led to an increase in their number. Ch. 458 of that year increased the number of judges to four, and this was continued in the revision

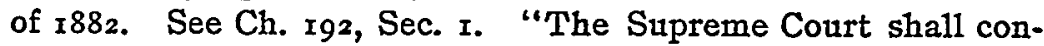
sist of a chief justice and four associate justices, to be elected, commissioned and to hold their offices as prescribed in the constitution." Section 3 provided as before that "any two justices thereof shall be a quorum for all purposes whatsoever."

Although ten different combinations of the five judges were possible, there could be but two courts sitting at the same time, except in those minor affairs where the law provided that one judge could sit alone. In May, I89I (Ch. 983), another associate justice was added to the court; in January, 1897 (Ch. $45 \mathrm{I}$ ), another was added and a quorum was made to consist of three judges.

The Supreme Court still consists of the chief justice and six associate justices. Of course, as the number of justices of the court increases, while the number necessary to constitute a quorum remains less than a majority of the whole number, with power to divide the court, the possible number of supreme courts increases rapidly. A radical change, but one of doubtful validity, was made under the revision of $r 893$, due in part to the fact that although we have continued to have a Supreme Court and also a court of common pleas, the jurisdiction of the Supreme Court has never been limited to the proper functions 
of a supreme court, the determination of all questions of law and of equity as a court of last resort, upon appeal from the court below, but it has always been made also a court of first instance concurrently with the court of common pleas, although, as required by the Constitution, it has remained our only court of equity. The radical change about to be explained was also partly due to the fact above set forth, that a quorum was made up of less than a majority of all its members, thus leaving it possible to have many supreme.courts. But this is practically what has been done, for under the Judiciary Act and the revision of 1896 , the Supreme Court was split into two divisionsthe appellate division and the common pleas division-thus making in effect. two courts out of the Supreme Court, although the Constitution says there shall be but one supreme court.

It was provided by the Judiciary Act (see Gen. Laws, Ch. 222) that the appellate division of the Supreme Court should consist of the chief justice and two associate justices to be designated from time to time by the chief justice. One judge was constituted a quorum for certain purposes; three, a quorum for all purposes, and two. when both parties consented.

When another judge was added to the court by $\mathrm{Ch} .45 \mathrm{x}$ in January, 1897 , no change was made in this respect.

The common pleas division of the Supreme Court was made to consist of the four remaining judges and one judge was made a quorum for all purposes. Ch. 223. It was provided "that whenever practicable as many more than three as possible of all the justices of the Supreme Court shall sit in the appellate division in the hearing and determination of constitutional questions." In this respect the Supreme Court remained the Supreme Court contemplated in the Constitution.

There has been increasing dissatisfaction among the members of the bar with this condition of the judiciary system. It was felt that it ought not to be possible to get around the provision of the Constitution that there shall be "one Supreme Court" by the simple expedient of splitting up the Supreme Court into separate courts and calling each one a division of the Supreme Court. Any attempt to divide a court that the Constitution declares is one court, must be illegal. The jurisdiction vested by the Constitution in this one court, cannot, by any device, be taken away from the whole of this one court and parceled out among divisions thereof. It follows that the appellate division of the Supreme Court created under General 
Laws Ch. 222 (amended, Pub. Laws, Ch. 45r), is not the Supreme Court contemplated by the Constitution. Neverthe. less, the Supreme Court upheld the validity of such legislation in the case of Mainz $v$. Lederer, 24 R. I., r66, in rgon, and decided that the Act of the General Assembly, creating an appellate division of the Supreme Court and limiting the number of its justices to four, is institutional, although the Supreme Court consists of seven justices.

A similar attempt about twenty years ago, to divide the Supreme Court of the United States, in order to lighten its labors, failed to meet with the approval of the bar. See the discussion thereon in the Reports of the American Bar Association from $I 882$ to 1885 .

The case of Floyd v. Quinn, 24 R. I. 147, in 1902, is another of the decisions of the Supreme Court of Rhode Island, the effect of which is still further to subordinate the court to the will of the legislature. The Court held that under the State Constitution, Article X, Section 2, providing, "The several courts shall have such jurisdiction as may from time to time be prescribed by 1aw," the General Assembly can regulate the jurisdiction of al1 the courts, and can give full jurisdiction to a minority of the justices to act for the court.

If the argument is sound that the one court established by the State Constitution cannot be broken up into separate courts by calling them divisions of the Supreme Court, it follows that chancery powers can be exercised only by the "one Supreme Court" established by Article ro, Section I. Section 2 provides "Chancery powers may be conferred on the Supreme Court, but on no other court to any greater extent than is now provided by law." In Williams v. Stearns, 126 Fed. Rep. $21 \mathrm{x}$, it was claimed that the decree in equity rendered by the three justices constituting the appellate division of the Supreme Court, sitting in equity, is not a decree in the exercise of the chancery powers conferred by the Constitution upon the Supreme Court, because not passed by a majority of the justices of the Supreme Court sitting in equity. The decree was contested in the United States Circuit Court for the District of Rhode Island, upon the ground that the course of the State Supreme Court was not "due process of law." The United States Court declined to grant relief.

To allay the feeling of dissatisfaction and to remove any possible doubt of constitutionality, as well as for other reasons, the General Assembly passed a resolution on March 
29, Igox, to submit to the people an amendment to the Constitution, the effect of which would be to embody in the Constitution itself the existing division of the Supreme Court into an appellate division and a common pleas division.

But the general sentiment of the bar was against it and at a business meeting of the Rhode Island Bar Association, held in the Court House in Providence, December 14, I901, upon the suggestion of James Tillinghast, Esq., the president of the association, Francis Colwell, Esq., was authorized to appoint a committee of five members to consider this matter and to report at a later meeting. The committee was appointed, consisting of Messrs. James Tillinghast, Edward D. Bassett, Walter H. Barney, Chatles E. Gorman and William A. Morgan.

They submitted their report January II, I902, at a business meeting of the Bar Association, reporting adversely as to the amendment proposed and submitting and recommending substantially the amendment since then adopted. Their report was adopted and the committee was instructed to appear before the General Assembly, to ask for the indefinite postponement of the measure proposed by the General Assembly and the adoption in its place of the measure proposed by the Bar Association. Aided by the lawyers in the General Assembly, by Governor Garvin, then a member of the House, and others, they succeeded, the amendment proposed was submitted by the General Assembly, to the electors and was accepted by the voters November 3,1903 . It is as follows:

\section{Article XII.}

"Section I. The supreme court shall have final revisory and appellate jurisdiction upon all questions of law and equity. It shall have power to issue prerogative writs, and shall also have such other jurisdiction as may, from time to time, be prescribed by law. A majority of its judges shall always be necessary to constitute a quorum. The inferior courts shall have such jurisdiction as may, from time to time be prescribed. by law.

"Sec. 2. The judges of the supreme court shall give their written opinion upon any question of law whenever requested by the Governor or by either house of the general assembly.

"Sec. 3. Sections $I$ and 2 of this amendment shall take, in the constitution of the state, the place of sections 2 and 3 of Article X., entitled "Of the Judicial Power," which sections are hereby annulled.

"Sec. 4. Section 3 of Article XIV of the constitution of the state, entitled, 'Of the Adoption of this Constitution' is hereby annulled. 
"Sec. 5. The general assembly'shall provide by law for carrying this amendment into effect, and until such provision shall be made the supreme court, as organized at the time of the adoption of this amendment, shall continue to have and exercise the same powers and jurisdiction which it shall then have under such organization."

During the winter of r9o4 the General Assembly appointed a commission to revise the judicial system of the state and their report will be submitted to the General Assembly at its session in January, r905. The way is clear at last for the establishment of a real court of appeals, a court of last resort, a quorum of which shall be constituted of a majority of all its members and whose function it shall be to hear and determine questions of law and of equity upon appeal.

Amasa M. Eaton. 